\title{
Study on Pathomorphological and Biochemical changes in Experimentally Induced Necrotic Enteritis in Broiler Chicken
}

\author{
K.C. Suryakanth ${ }^{1}$, M.L. Sathyanarayan ${ }^{1}$, K.C. Mallinath ${ }^{2}$, H.D. Narayanaswamy ${ }^{1 *}$, \\ Shravan Kumar ${ }^{1}$, G. Sugunarao ${ }^{1}$, Upendra ${ }^{3}$ and N.B. Shridhar ${ }^{3}$ \\ ${ }^{1}$ Department of Veterinary Pathology, Veterinary College, KVAFSU, Bengaluru \\ ${ }^{2} I A H \& V B$, Bengaluru, India \\ ${ }^{3}$ Veterinary College, Bengaluru, India
}

*Corresponding author

\section{A B S T R A C T}

\begin{tabular}{|l|}
\hline Ke y w o r d s \\
Necrotic enteritis, \\
Clostridium, \\
Eimeria, Broiler \\
chicken and \\
Livacox
\end{tabular}

\section{Introduction}

Necrotic Enteritis is a disease of major economic importance affecting the poultry industry worldwide. Globally, the cost of the disease estimated to be over US $\$ 2$ billion per year due to production losses and treatment expenses. The causative agents of Necrotic Enteritis are Clostridium perfringens toxin Type A strains which produce the Net B toxin (Keyburn et al., 2010).The disease is common in 2 to 6 week old broiler chicken occurring mainly in three different forms i.e., clinical, subclinical and mild form. The onset of

\begin{abstract}
The present work was carried out to study the patho-morphological and biochemical changes in experimentally induced Necrotic enteritis in broiler chicken. Two experimental groups T1 \& T2 each comprising of 40 day old female broiler chicks, were fed with normal feed on day 1 to 16 . On day $17^{\text {th }}, 18^{\text {th }}, 19^{\text {th }}$ and $20^{\text {th }}$, they were orally administered with Clostridium perfringens at the dose rate of $4 \mathrm{X} 10^{8} \mathrm{CFU}$ per bird thrice a day along with 10 times the dose of Livacox vaccine on day $18^{\text {th }}$ then from day 21 to 42 normal feed was fed to both the groups. There was significant difference in the parameters such as body weight, feed consumption, FCR, serum AST, ALT, total proteins. Impression smears of intestine showed significant gross and histopathological changes in the clostridium challenged birds compared to normal control.
\end{abstract}

Necrotic enteritis is, however, a multifactorial event in which subclinical coccidiosis is believed to be one of the major predisposing factors along with high protein and high wheat composition in the diet. Hence present study was undertaken to know the changes in pathomorphological and biochemical parameters in experimentally induced necrotic enteritis in broiler chicken.

\section{Materials and Methods}

The study was carried out in broiler chicken at Department of Veterinary Pathology, 
Veterinary College, KVAFSU, Hebbal, Bangalore-560024, for a period of 42 days with prior approval of the Institutional Animal Ethical Committee of Veterinary College Bangalore.

\section{Experimental chicks}

An in vivo study was carried out using a day old female broiler chicks distributed in two groups, each comprising 40 chicks. The groups were reared in cages with a density of ten birds/6sq. ft in two-tier system and standard management practices were followed to rear them.

The birds were fed with starter, grower and finisher feed as per age of the bird during the period of experiment. Prophylactically vaccination and medication was administered as per standard protocol.

\section{Strain of Bacteria and Coccidia vaccine}

The Clostridium perfringens Type A (ATCC No. 13124) organisms were procured from National Chemical Laboratory, National Collection of Industrial Microorganisms (NCIM), Pune, Maharashtra. The Livacox, a live attenuated coccidiosis vaccine containing 30,000 to 50,000 of each of attenuated lines of Eimeria acervulina, Eimeria maxima and Eimeria tenella and 10,000 oocysts of Eimeria necatrix in $1 \%$ water solution of Chloramine B procured from M/S Elanco, Bangalore.

\section{Experimental design}

The chicks were divided into two groups with 40 chicks in each group weighing equally on Day 1.

Group 1 (T1) - Birds fed with normal feed and non challenged (Normal control) and used for studying base line values of the parameters.
Group 2 (T2) - Birds challenged with Clostridium perfringens (Clostridia challenged)

\section{Experimental induction of Necrotic Enteritis}

Three periods during the study were well separated ie., pre-challenge, challenge and post challenge.

Pre challenge: Day1 to 16 where in, a normal feed was fed to the birds in T1 and T2.

Challenge: The birds in group T2 was challenged with Clostridium perfringens on Day 17, 18, 19 and 20 and given coccivac vaccine with ten folds dilution on Day 18.

Post challenge: Comprised a period from Day 21 to 42 where a normal feed was fed to both the groups.

Challenge: The birds were challenged according to the method described by Lankriet et al, (2010). Broilers were fed a conc $(45-55 \%)$ diet, with soybean meal as protein source. From Day 17 onwards, the same diet was used with the exception that fishmeal (30\%) replaced soy bean as the protein source. Prior to challenge, the birds of the group T2 were starved overnight to induce stress. They were administered orally using a sterile plastic syringe (Three times a day) with approximately $4 \times 10^{8}$ colony-forming units of Clostridium perfringens bacteria on Days 17, 18, 19 and 20. On Day 18, all birds were orally administered with a ten-fold dose of Coccivac.

\section{Clinical observations}

Birds of both the groups were observed for feed and water intake, general behaviour, alertness, diarrhoea and any other clinical symptoms. 


\section{Collection of serum samples}

About $5 \mathrm{ml}$ of blood was collected from each bird of both the groups separately during sequential sacrifices i.e., on $22^{\text {nd }}, 24^{\text {th }}, 26^{\text {th }}$ and $42^{\text {nd }}$ days of the experiment. The serum was separated and stored at $-20^{\circ} \mathrm{C}$ until subjected for ALT, AST and Total protein estimation.

\section{Sequential pathology}

Ten birds from the T2-Group were euthanized sequentially to study the challenge effect. Gross changes if any were recorded during post-mortem examination. Representative tissue samples from different segments of intestine (Duodenum, Jejunum, Ileum and Caecum) and liver 3-5 mm thickness were collected in ten per cent neutral buffered formalin (NBF) for histopathology (Luna, 1968).

\section{Parameters analyzed}

Parameters like daily feed consumption, weekly body weight and biochemical parameters like AST, ALT \& TP were analyzed as per standard protocol followed by Tietz, (1976)

\section{Statistical analysis}

Statistical analysis was performed with statistical software SPSS Statistics 17.0 software (SPSS Inc., Chicago, Illinois, USA). Mean values and standard error for the total serum protein, AST and ALT values were analysed using one way analysis of variance (ANOVA) and were expressed as mean $( \pm$ SE).

\section{Results and Discussion}

Necrotic Enteritis is primarily a disease of young chickens caused by infection with a toxin produced by Clostridium perfringens Type A, and to lesser extent by Type C organism (Songer and Meer, 1997).

\section{Experimental induction}

In the current study, Necrotic enteritis was induced in Group T2 (Clostridia challenged) by oral administration of Clostridium perfringens Type A bacteria on Day 17, 18, 19,20 at the dose rate of $4 \times 10^{8}$ cfu per bird per inoculation (Three times a day) as described by Olkowski et al., (2006) and Pedersen et al., (2008).

On Day 18, all birds were orally inoculated with a ten-fold dose of Coccivac in order to create predisposing condition which results in intestinal damage leading to release of plasma proteins into the lumen of the intestinal tract. This provides 11 amino acids which acts as necessary growth substrate for extensive proliferation of these bacteria and thus leading to necrosis of intestinal epithelium (Baba et al., 1992; Kaldhusdal et.al., 1999).

\section{Clinical signs}

In the present study, the group challenged with Clostridium perfringens showed apparent clinical signs like of depression, reluctance to move, loss of appetite, ruffled feathers, drooping of wings and head, diarrhoea, dehydration, reduced growth rate and an inclination to huddle together under the heat source and no signs are observed in normal control group (Fig. 1).

\section{Performance}

\section{Feed consumption $(\mathrm{g})$}

The mean $( \pm \mathrm{SE})$ feed consumption of $\mathrm{T} 1$ Group (Normal control) showed gradual increase in feed intake from $1^{\text {st }}$ to $6^{\text {th }}$ week. The mean $( \pm \mathrm{SE})$ feed consumption of $\mathrm{T} 2$ 
Group (Clostridia challenged) birds were observed to be normal during $1^{\text {st }}$ and $2^{\text {nd }}$ week; There was progressive decrease in the rate of feed intake from $3^{\text {rd }}$ to $6^{\text {th }}$ week. The mean feed consumption from $3^{\text {rd }}$ to $6^{\text {th }}$ week was significantly lower $(\mathrm{P} \leq 0.05)$ when compared with normal control bird (Table 1).

\section{Feed Conversion Ratio (FCR)}

The mean $( \pm$ SE) FCR values of T2 group (Clostridia challenged) showed a normal FCR during $1^{\text {st }}$ to $3^{\text {rd }}$ week and an increase in FCR values from $4^{\text {th }}$ to $6^{\text {th }}$ week respectively, which were significantly higher $(\mathrm{P} \leq 0.05)$ compared to normal control birds (Table 1)

\section{Serum biochemistry}

\section{Serum AST and ALT}

Birds of the Group T2 (Clostridia challenged) showed a significant increase $(\mathrm{P} \leq 0.05)$ in the mean $( \pm \mathrm{SE})$ serum aspartate amino transferase (AST) and Alanine amino transferase (ALT) values when compared with normal group, which could be attributed to hepatic degeneration, necrosis and subsequent leakage of enzymes. AST and ALT are leakage enzymes present in the cytosol and organelles of hepatocytes (Table 2). Usually there is high concentration gradient between the hepatocytes and the sinusoidal space for enzymes. Cell damage increases permeability causing cytosolic isoenzymes to spill into the sinusoids and from there to peripheral blood (Shane et al., 1985).The birds of normal control (T1) group also maintained a constant mean serum AST and ALT levels throughout the experiment.

\section{Serum total protein (TP)}

In the present study, the mean $( \pm$ SE) Serum total protein (TP) values of Clostridia challenged (T2) birds were significantly lower
$(\mathrm{P} \leq 0.05)$ compared to normal control (T1) birds (Table 2). The reduction in the total protein levels could be due to degeneration of endoplasmic reticulum in hepatocytes and covalent binding of Clostridial metabolites to template RNA. This process causes inhibition of transcription steps in protein synthesis as reported by Shane et al., (1985).

\section{Gross pathology: (Table 3)}

\section{Small intestine}

In the present investigation, birds in the $\mathrm{T} 1$ (Normal control) group did not reveal any morphological derangement in any of the segments of the intestine throughout the experimental study. While birds in the T2 Group which were infected with Clostridium perfringens revealed distended thin walled duodenum. Serosal surface appeared dull pink, with engorged serosal vessels. The mesenteric vessels were engorged with blood. Mucosal surface of the duodenum showed patches of haemorrhages and focal areas of necrosis, with brown colour diphtheritic membrane (Kaldhusdal and Hofshagen, 1992). Jejunum and ileum revealed focal areas of necrosis, patches of multifocal haemorrhages and thin walled, containing blood tinged flocculent fluid. Mucosal surface covered with yellow to green sometimes grey to brown colour diphtheritic membrane. Serosal surface appeared dull pink, with engorged vessels (Fig. 2-6).

The findings in the experiment were in accordance with findings of Long and Barnum, (1974), Broussard et al., (1986). They opined that various gross lesions in the duodenum, jejunum and ileum could be due to production of $\alpha$ toxin by Clostridium perfringens bacteria which stimulates the arachidonic acid cascade to induce the production of inflammatory mediators like leucotrienes, prostacyclins, platelet activating 
factor and thromboxanes which contribute for contraction of blood vessels and aggregation of platelets leading to above changes.

\section{Large intestine}

In the present study, normal control birds did not show any gross lesions in the large intestine throughout the experimental study. Birds challenged with Clostridium perfringens (T2) showed various lesions in the Caecum viz., irregular, focal or locally extensive depressions on the mucosal surface, multifocal or locally extensive haemorrhages with focal areas of necrosis in the ceacal tonsils. Mucosa was lined by yellow or greenish, loosely adherent pseudo-membrane. All the above lesions could be attributed to production of $\alpha$ toxin by the bacterium and similar observations were made by Gholamiandehkordi et al., (2007).

\section{Liver}

Birds in the T1 (Normal control) group did not reveal any lesions in the liver and appeared normal. Clostridia challenged (T2) birds showed focal areas of necrosis and haemorrhages with discolouration of the extra-hepatic bile tree and occasional focal subcapsular nodules. These lesions observed in the liver of Clostridia challenged (T2) birds suggested that $\alpha$ toxin produced in the intestine by the Clostridium perfringens through entero hepatic circulation reached liver and caused damage to the liver tissue (Lovland and Kaldhusdal, 1998).

\section{Histopathology}

\section{Small intestine}

Microscopically, birds belonging to Groups T1 (Normal control) did not show any pathological changes in the small intestine (Fig.7-9). Clostridia challenged (T2) birds' revealed degeneration and desquamation of surface epithelium which could be attributed to direct effect of alpha toxin of Clostridium perfringens on the cellular membranes which results in segmental loss of mucosal epithelial cells. Increased goblet cell activity could be due to intestinal irritation caused by Clostridial organisms and its toxins on the surface epithelial cells. Distension of lacteals, congestion, focal haemorrhages in the tip and core of villi attributed to inflammatory changes initiated by Clostridium perfringens which stimulates the arachidonic acid cascade to induce the production of inflammatory mediators like leucotrienes, prostacyclins, platelet activating factor and thromboxanes, which leads to contraction of blood vessels and aggregation of platelets (Titball et al., 1993). Marked to diffuse coagulative necrosis of the mucosal layer of the small intestine, severe necrosis involving luminal third to half of mucosa, delimited intestinal epithelium with few masses of tissue fragments, necrotic cells and numerous bacterial colonies suspended in mucus matrix with formation of pseudo-membrane were the other features observed in the present study. This could be related to production of $\alpha$ toxin by Clostridium perfringens which causes disorganization of mucus membrane leading to cell death (Songer and Meer, 1997) (Fig. 10-15).

\section{Large intestine}

Birds in the normal control group showed normal architecture of the large intestine throughout the experimental study (Fig. 16). Group T2 (Clostridia challenged) birds revealed denudation and necrosis of the epithelial layer of the submucosa, moderate to severe degree of goblet cell activity, presence of clusters of organisms freely as well as adhered to the cell surface and patches of multifocal haemorrhagic areas covering the lamina-propria and lamina-muscularis. There 
was also infiltration of inflammatory cells in the lamina propria of the sub mucosa. All these findings suggested effect of clostridium infection in the challenged group as observed by Smyth and Martin, (2010) (Fig.17- 19).

Table.1 The mean $( \pm \mathrm{SE})$ body weight $(\mathrm{gm})$, Feed consumption and FCR values of Normal control, Clostridia challenged, Groups at weekly intervals of time

\begin{tabular}{|c|c|c|c|c|c|c|c|}
\hline \multirow[t]{2}{*}{ Parameters } & \multirow{2}{*}{$\begin{array}{l}\text { Treatment } \\
\text { Groups }\end{array}$} & \multicolumn{6}{|c|}{ Different time intervals } \\
\hline & & $1^{\text {st }}$ Week & $2^{\text {nd }}$ Week & $3^{\text {rd }}$ Week & $4^{\text {th }}$ Week & $5^{\text {th }}$ Week & $6^{\text {th }}$ Week \\
\hline \multirow[t]{2}{*}{ Body weight } & $\begin{array}{l}\text { T1 (Normal } \\
\text { control) }\end{array}$ & $\begin{array}{c}91.68 \pm \\
4.17^{\mathrm{a}}\end{array}$ & $\begin{array}{c}310.58 \pm \\
20.56^{\mathrm{a}}\end{array}$ & $\begin{array}{c}648.83 \pm \\
20.19^{\mathrm{b}}\end{array}$ & $\begin{array}{l}1197.5 \pm \\
14.03^{\mathrm{c}}\end{array}$ & $\begin{array}{c}1757.8 \pm \\
24.0^{\mathrm{c}}\end{array}$ & $\begin{array}{c}2145.3 \pm \\
58.28^{\mathrm{b}}\end{array}$ \\
\hline & $\begin{array}{l}\text { T2 (Clostridia } \\
\text { challenged) }\end{array}$ & $\begin{array}{l}90.13 \pm \\
1.33^{\mathrm{a}}\end{array}$ & $\begin{array}{c}302.95 \pm \\
6.63^{\mathrm{a}}\end{array}$ & $\begin{array}{c}553.25 \pm \\
13.92^{\mathrm{a}}\end{array}$ & $\begin{array}{l}890.00 \pm \\
13.52^{\mathrm{a}}\end{array}$ & $\begin{array}{c}1320.13 \pm \\
58.4^{\mathrm{a}}\end{array}$ & $\begin{array}{c}1718.45 \pm \\
41.3^{\mathrm{a}}\end{array}$ \\
\hline \multirow[t]{2}{*}{$\begin{array}{c}\text { Feed } \\
\text { Consumption }\end{array}$} & $\begin{array}{l}\text { T1 (Normal } \\
\text { control) }\end{array}$ & $\begin{array}{c}171.98 \pm \\
9.1^{\mathrm{a}}\end{array}$ & $\begin{array}{c}476.92 \pm \\
26.80^{\mathrm{a}}\end{array}$ & $\begin{array}{c}912.45 \pm \\
23.86^{\mathrm{b}}\end{array}$ & $\begin{array}{c}2184.70 \pm \\
101.68^{\mathrm{b}}\end{array}$ & $\begin{array}{c}3032.69 \pm \\
146.27^{\mathrm{b}}\end{array}$ & $\begin{array}{c}3831.17 \pm \\
203.28^{\mathrm{b}}\end{array}$ \\
\hline & $\begin{array}{l}\text { T2 (Clostridia } \\
\text { challenged) }\end{array}$ & $\begin{array}{c}171.95 \pm \\
10.50^{\mathrm{a}}\end{array}$ & $\begin{array}{c}488.70 \pm \\
19.85^{\mathrm{a}}\end{array}$ & $\begin{array}{l}810.00 \pm \\
5.15^{\mathrm{a}}\end{array}$ & $\begin{array}{c}1889.00 \pm \\
44.44^{\mathrm{a}}\end{array}$ & $\begin{array}{c}2734.50 \pm \\
77.57^{\mathrm{a}}\end{array}$ & $\begin{array}{c}3473.25 \pm \\
137.06^{\mathrm{a}}\end{array}$ \\
\hline \multirow[t]{2}{*}{ FCR } & $\begin{array}{l}\text { T1 (Normal } \\
\text { control) }\end{array}$ & $\begin{array}{l}1.89 \pm \\
0.13^{\mathrm{a}}\end{array}$ & $\begin{array}{l}1.56 \pm \\
0.15^{\mathrm{a}}\end{array}$ & $\begin{array}{l}1.41 \pm \\
0.08^{\mathrm{a}}\end{array}$ & $\begin{array}{l}1.82 \pm \\
0.07^{\mathrm{a}}\end{array}$ & $\begin{array}{l}1.72 \pm \\
0.07^{\mathrm{a}}\end{array}$ & $\begin{array}{l}1.78 \pm \\
0.06^{\mathrm{a}}\end{array}$ \\
\hline & $\begin{array}{l}\text { T2 (Clostridia } \\
\text { challenged) }\end{array}$ & $\begin{array}{l}1.91 \pm \\
0.13^{\mathrm{a}}\end{array}$ & $1.6 \pm 0.05^{\mathrm{a}}$ & $\begin{array}{l}1.47 \pm \\
0.04^{\mathrm{a}}\end{array}$ & $\begin{array}{l}2.12 \pm \\
0.07^{\mathrm{b}}\end{array}$ & $\begin{array}{l}2.02 \pm \\
0.14^{b}\end{array}$ & $\begin{array}{l}2.02 \pm \\
0.08^{\mathrm{b}}\end{array}$ \\
\hline
\end{tabular}

All the values are expressed as mean $( \pm \mathrm{SE})$, The values between the Groups for each week with super script $\mathrm{a}, \mathrm{b}$, and $\mathrm{c}$ are statistically significant at $\mathrm{P} \leq 0.05$

Table.2 The mean ( \pm SE) AST, ALT (IU/L) and Total Protein (g/dL) values of Normal control, Clostridia challenged, Groups at different time intervals

\begin{tabular}{|c|c|c|c|c|c|}
\hline \multirow[t]{2}{*}{ Parameters } & \multirow{2}{*}{$\begin{array}{c}\text { Treatment } \\
\text { Groups }\end{array}$} & \multicolumn{4}{|c|}{ Sequential sacrifice } \\
\hline & & $\begin{array}{c}1^{\text {st }} \text { Sacrifice } \\
\text { (Day 22) }\end{array}$ & $\begin{array}{c}2^{\text {nd }} \\
\text { Sacrifice } \\
\text { (Day 24) }\end{array}$ & $\begin{array}{c}3^{\text {rd }} \\
\text { Sacrifice } \\
\text { (Day 26) }\end{array}$ & $\begin{array}{c}4^{\text {th }} \text { Sacrifice } \\
\text { (Day 42) }\end{array}$ \\
\hline \multirow[t]{2}{*}{ AST } & $\begin{array}{l}\text { T1 (Normal } \\
\text { Control) }\end{array}$ & $\begin{array}{c}174.91 \pm \\
0.14^{\mathrm{a}}\end{array}$ & $\begin{array}{c}176.10 \pm \\
0.58^{\mathrm{a}}\end{array}$ & $\begin{array}{c}173.69 \pm \\
1.89^{\mathrm{a}}\end{array}$ & $\begin{array}{c}172.62 \pm \\
3.40^{\mathrm{a}}\end{array}$ \\
\hline & $\begin{array}{c}\text { T2 } \text { (Clostridia } \\
\text { challenged) }\end{array}$ & $\begin{array}{c}197.30 \pm \\
2.02^{\mathrm{b}}\end{array}$ & $\begin{array}{c}204.30 \pm \\
2.09^{\mathrm{b}}\end{array}$ & $\begin{array}{c}202.86 \pm \\
3.89^{\mathrm{b}}\end{array}$ & $\begin{array}{c}190.97 \pm \\
4.19^{\mathrm{b}}\end{array}$ \\
\hline \multirow[t]{2}{*}{ ALT } & $\begin{array}{c}\text { T1 (Normal } \\
\text { Control) }\end{array}$ & $\begin{array}{c}24.97 \pm \\
1.61^{\mathrm{a}}\end{array}$ & $\begin{array}{c}27.86 \pm \\
0.90^{\mathrm{a}}\end{array}$ & $\begin{array}{c}29.55 \pm \\
1.11^{\mathrm{a}}\end{array}$ & $\begin{array}{c}29.78 \pm \\
2.92^{\mathrm{a}}\end{array}$ \\
\hline & $\begin{array}{c}\text { T2 (Clostridia } \\
\text { challenged) }\end{array}$ & $\begin{array}{c}51.42 \pm \\
9.17^{\mathrm{b}}\end{array}$ & $\begin{array}{c}53.50 \pm \\
11.74^{\mathrm{b}}\end{array}$ & $\begin{array}{c}48.38 \pm \\
4.09^{\mathrm{b}}\end{array}$ & $\begin{array}{c}45.46 \pm \\
6.26^{\mathrm{b}}\end{array}$ \\
\hline \multirow[t]{2}{*}{ TP } & $\begin{array}{l}\text { T1 (Normal } \\
\text { control) }\end{array}$ & $\begin{array}{c}56.42 \pm \\
0.15^{\mathrm{b}}\end{array}$ & $\begin{array}{c}55.24 \pm \\
0.37^{\mathrm{b}}\end{array}$ & $\begin{array}{c}55.65 \pm \\
0.58^{\mathrm{b}}\end{array}$ & $\begin{array}{c}56.18 \pm \\
0.19^{\mathrm{b}}\end{array}$ \\
\hline & $\begin{array}{c}\text { T2 (Clostridia } \\
\text { challenged) }\end{array}$ & $\begin{array}{c}32.19 \pm \\
1.60^{\mathrm{a}}\end{array}$ & $\begin{array}{c}27.84 \pm \\
2.23^{\mathrm{a}}\end{array}$ & $\begin{array}{c}29.99 \pm \\
1.63^{\mathrm{a}}\end{array}$ & $\begin{array}{c}24.07 \pm \\
1.71^{\mathrm{a}}\end{array}$ \\
\hline
\end{tabular}

All the values are expressed as mean $( \pm \mathrm{SE})$, The values between the Groups for each sacrifice with super script a and $b$ are statistically significant at $P \leq 0.05$ 
Table.3 Gross lesions observed in birds infected with Clostridium perfringens (T2) at different time intervals (Sequential sacrifice)

\begin{tabular}{|c|c|c|c|c|c|c|c|}
\hline \multirow{3}{*}{$\begin{array}{l}\text { Different } \\
\text { segments of } \\
\text { intestine } \\
\text { examined }\end{array}$} & Time intervals in days & $22^{\text {nd }}$ & $24^{\text {rth }}$ & $26^{\text {th }}$ & $42^{\text {nd }}$ & Total & $\%$ \\
\hline & $\begin{array}{c}\text { No of birds } \\
\text { examined }\end{array} \longleftrightarrow$ & 10 & 10 & 10 & 10 & 40 & 100 \\
\hline & Type of lesions $冗$ & & & & & & \\
\hline \multirow[t]{4}{*}{ Duodenum } & Congestion & 8 & 10 & 8 & 9 & 35 & 87.50 \\
\hline & Hemorrhage & 8 & 9 & 8 & 7 & 32 & 80.00 \\
\hline & Necrosis & 9 & 8 & 8 & 6 & 31 & 77.50 \\
\hline & Pseudomembrane formation & 1 & 2 & 3 & 1 & 7 & 17.50 \\
\hline \multirow[t]{4}{*}{ Jejunum } & Congestion & 9 & 10 & 10 & 8 & 37 & 92.50 \\
\hline & Hemorrhage & 7 & 8 & 9 & 8 & 32 & 80.00 \\
\hline & Necrosis & 9 & 10 & 10 & 9 & 38 & 95.00 \\
\hline & Pseudomembrane formation & 1 & 2 & 4 & 1 & 8 & 20.00 \\
\hline \multirow[t]{4}{*}{ Ileum } & Congestion & 7 & 8 & 8 & 8 & 31 & 77.50 \\
\hline & Hemorrhage & 7 & 7 & 8 & 7 & 29 & 72.50 \\
\hline & Necrosis & 9 & 10 & 9 & 8 & 36 & 90.00 \\
\hline & Pseudomembrane formation & 0 & 2 & 2 & 1 & 4 & 10.00 \\
\hline \multirow[t]{4}{*}{ Caecum } & Congestion & 8 & 9 & 9 & 8 & 34 & 85.00 \\
\hline & Hemorrhage & 8 & 7 & 7 & 6 & 28 & 70.00 \\
\hline & Necrosis & 9 & 7 & 8 & 8 & 32 & 80.00 \\
\hline & Pseudomembrane formation & 1 & 4 & 3 & 1 & 9 & 22.50 \\
\hline
\end{tabular}

Fig.1 Photograph to show Clostridia challenged (T2) bird compared with the Normal control (T1) bird on 42nd day of experiment. Note the variation in body size, condition and feather pattern of birds

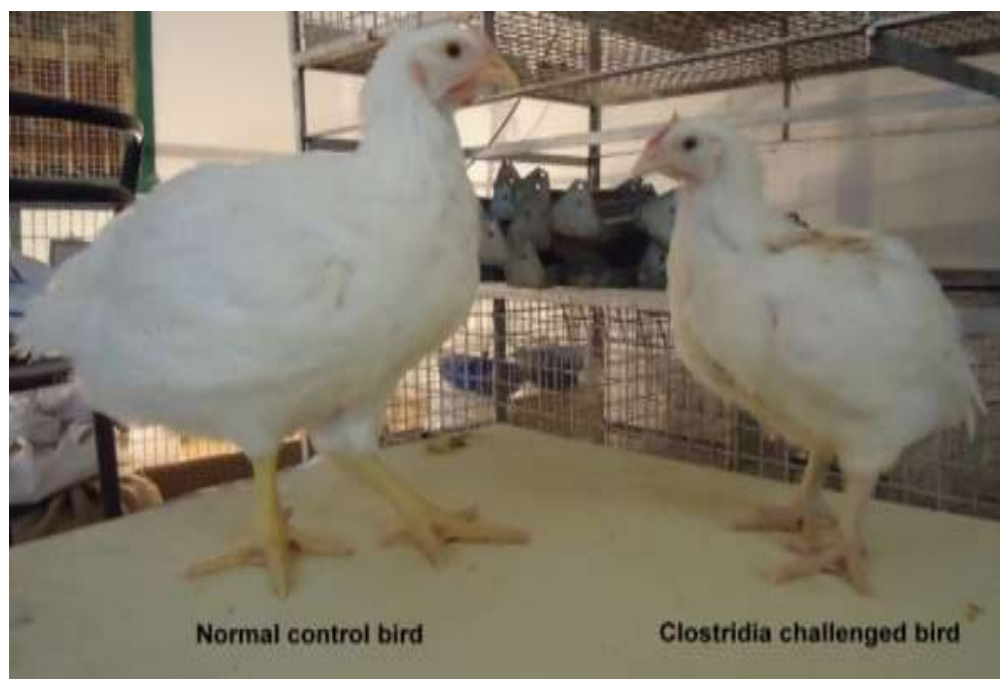


Fig.2 Photograph to show serosal surface of intestine from Clostridia challenged (T2) bird. Note the haemorrhagic patches, focal areas of necrosis with engorged serosal vessels on 42nd day of experiment

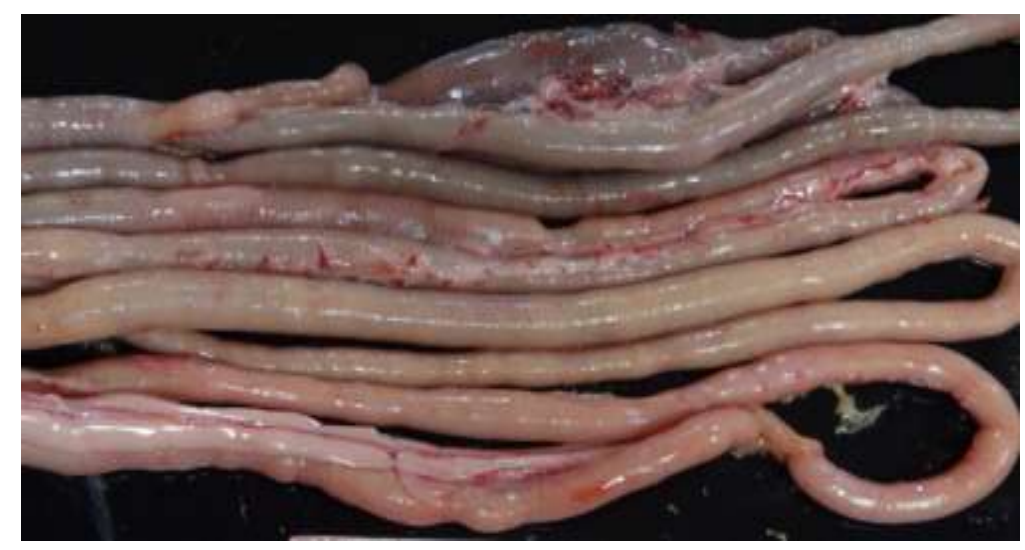

Fig.3 Photograph of mucosal surface of ileum from Clostridia challenged (T2) bird to show patches of haemorrhages with green to yellow diphtheritic membrane

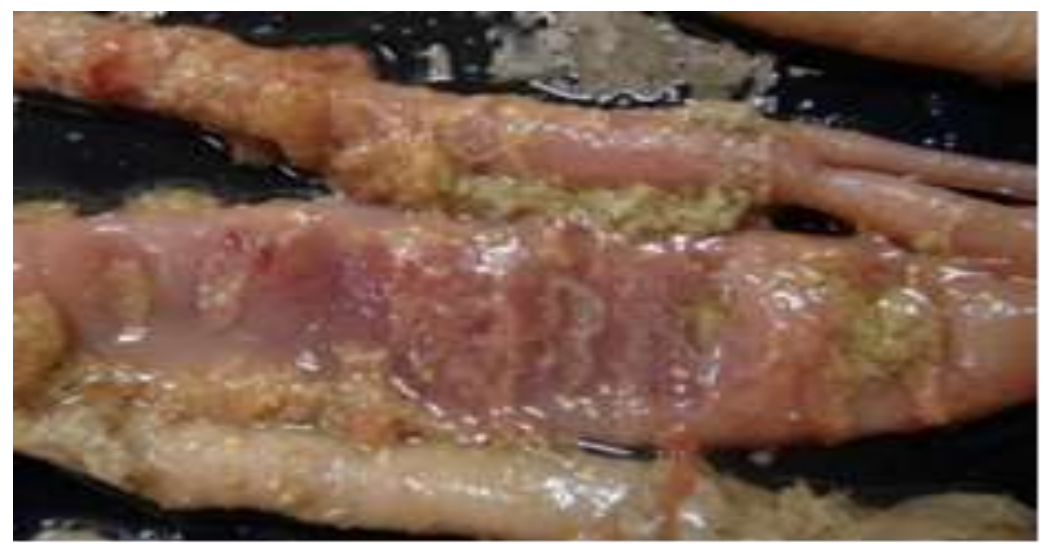

Fig.4 Photograph of Duodenum from Clostridia challenged (T2) bird to show extensive haemorrhages spreading almost whole length of the duodenum on 24th day of the experiment

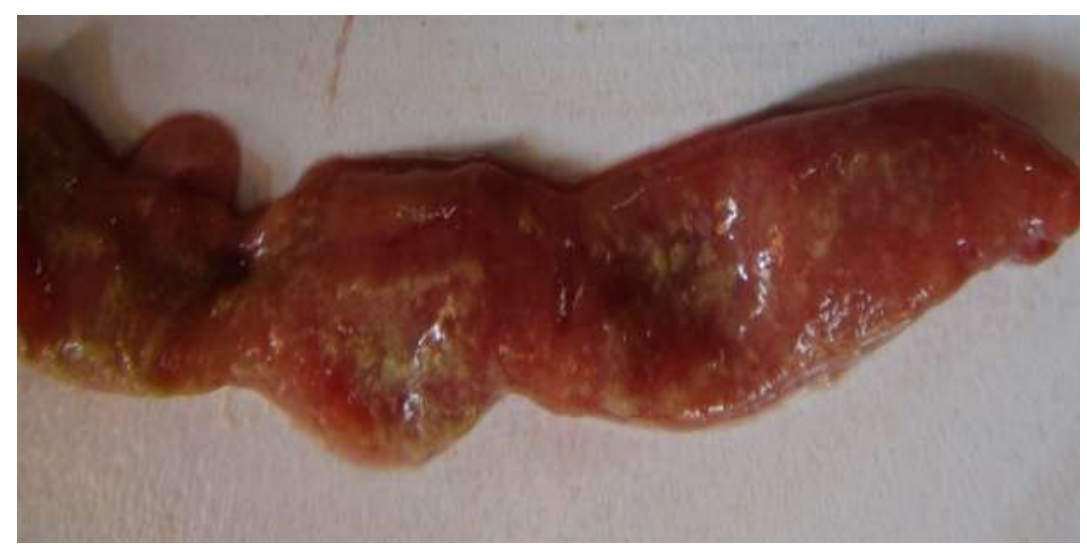


Fig.6 Photograph of Jejunum from Clostridium infected bird (T2) showing sloughing off mucosal epithelium and pseudomembrane formation, on 26th day of the experiment

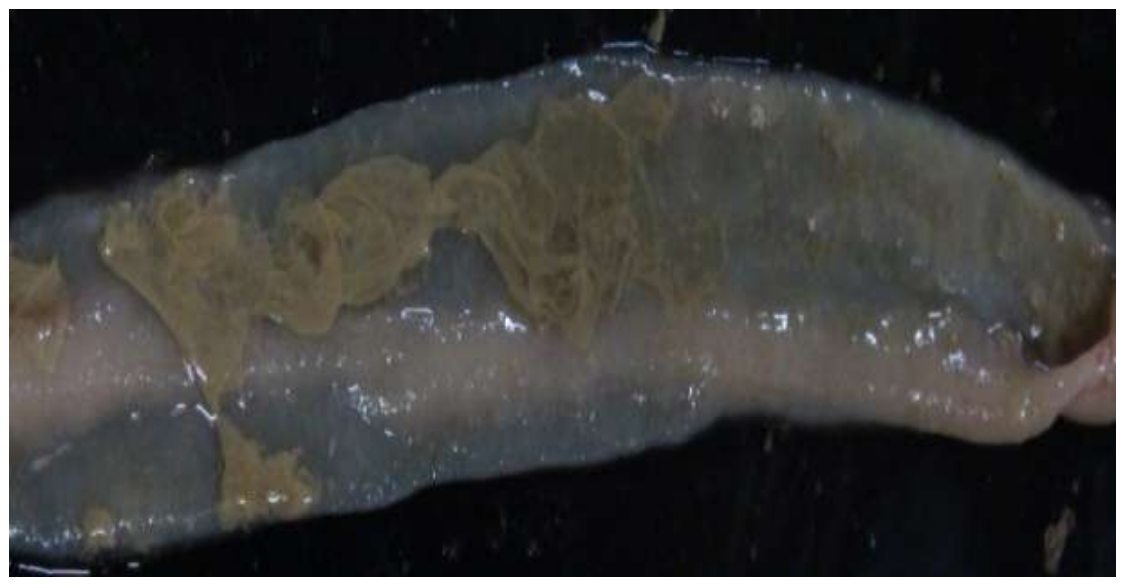

Fig.7 Photomicrograph of jejunum from Normal control (T1) bird to show intact villus architecture on 24th day of the study. H\&E X 100

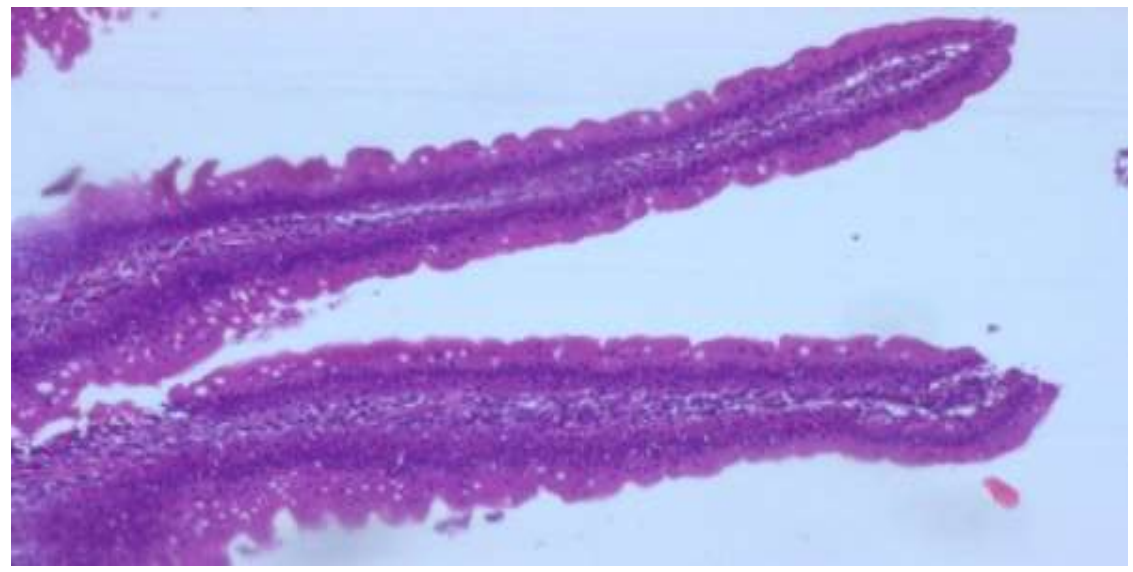

Fig.8 Photomicrograph of duodenum from Normal control (T1) bird to show normal intact villus architecture on 24th day of the experiment. H\&E X 200

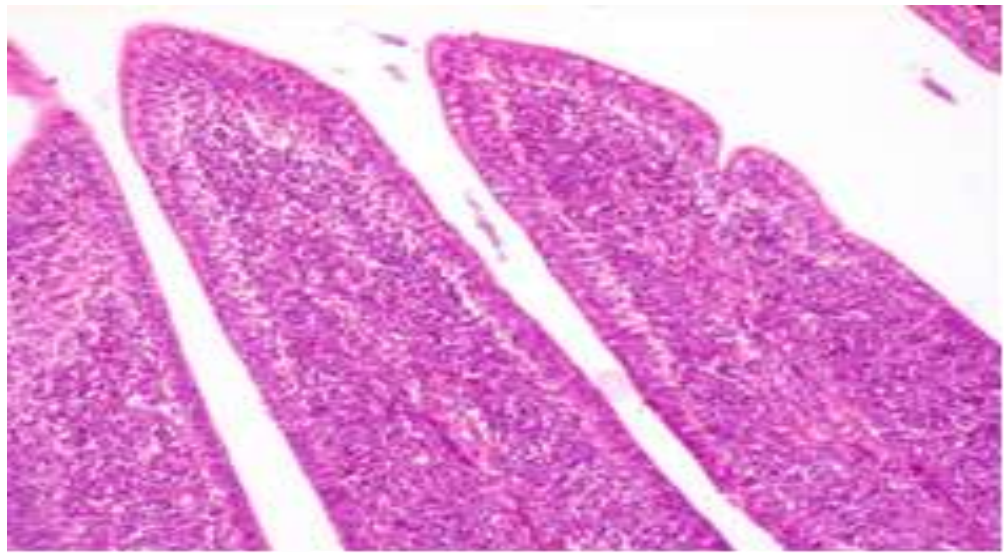


Fig.9 Section of ileum from Normal control (T1) bird to show normal villus architecture on day 24th of the experiment. H\&E X 200

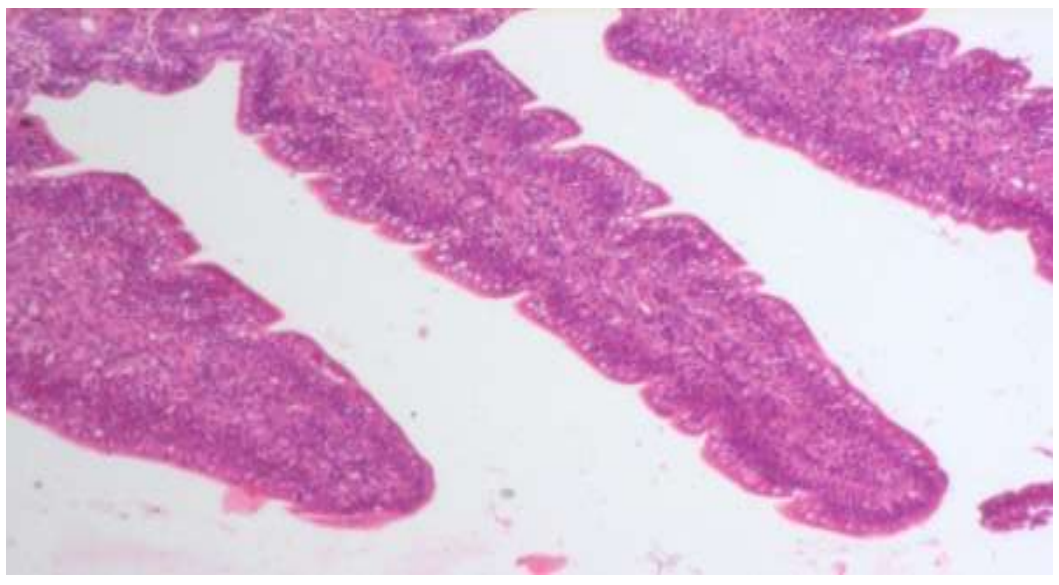

Fig.10 Section of duodenum from Clostridia challenged (T2) bird to show denudation and desquamation of superficial epithelial layer of tunica mucosa on day 26 nd of the experiment. $\mathrm{H} \& \mathrm{E}$ X 40

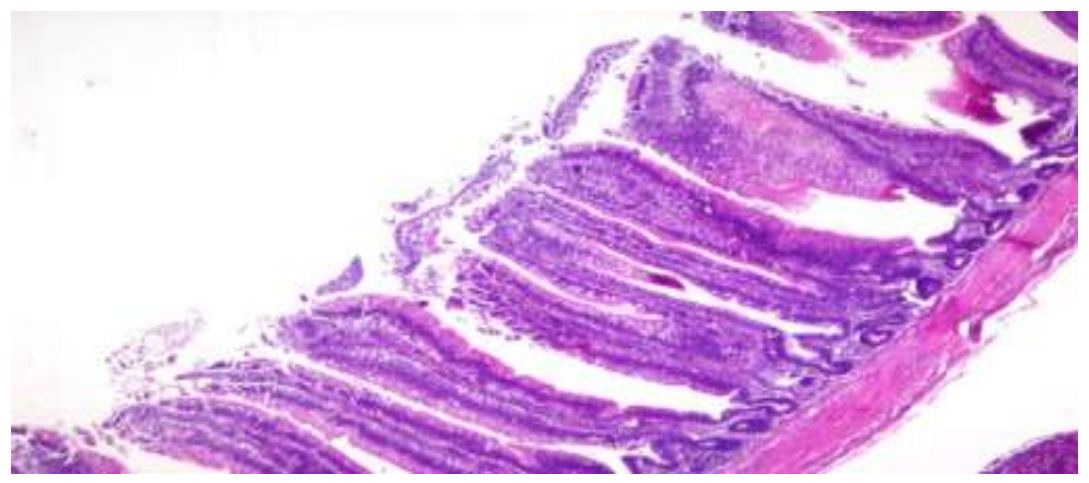

Fig.11 Photomicrograph of jejunum from Clostridia challenged (T2) bird to show denudation, desquamation of superficial epithelial layer of tunica mucosa on 24 th day of experiment. H\&E X 40

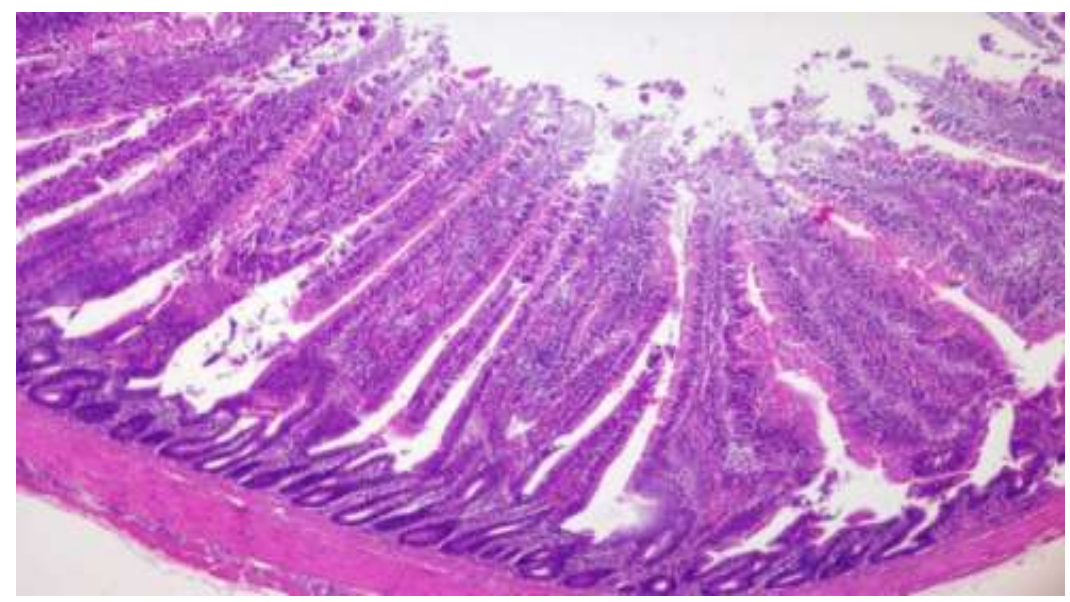


Fig.12 Photomicrograph of jejunum from Clostridia challenged (T2) bird to show denudation of villus epithelium with areas of necrosis, mononuclear cell infiltration and haemorrhages on 26th day of the study. H\&E X 100

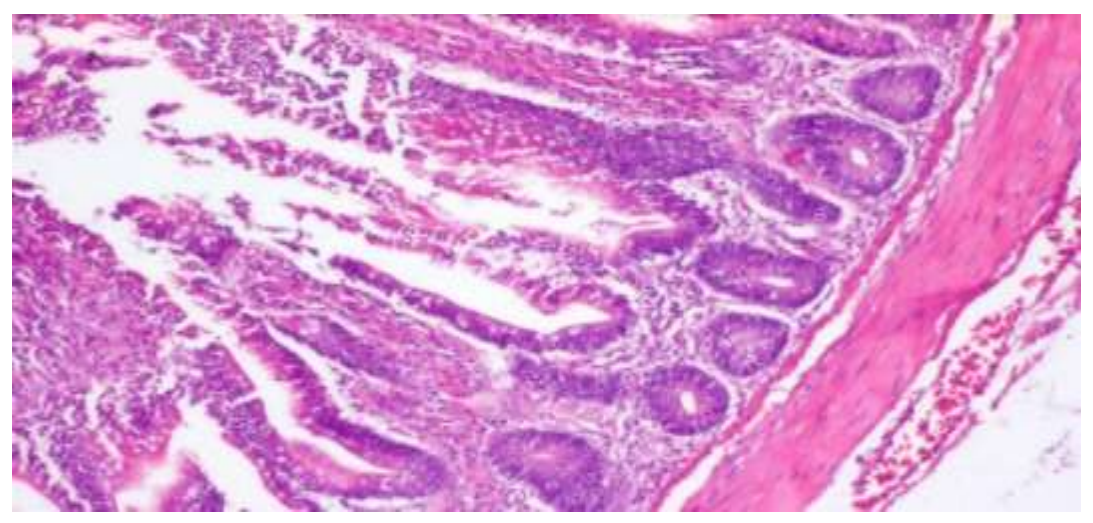

Fig.13 Photomicrograph of ileum from Clostridia challenged (T2) bird to show haemorrhages, mononuclear cell infiltration, oedema at the basement membrane, necrosis and detachment of epithelium on 24th day of the experiment. H\&E X 200

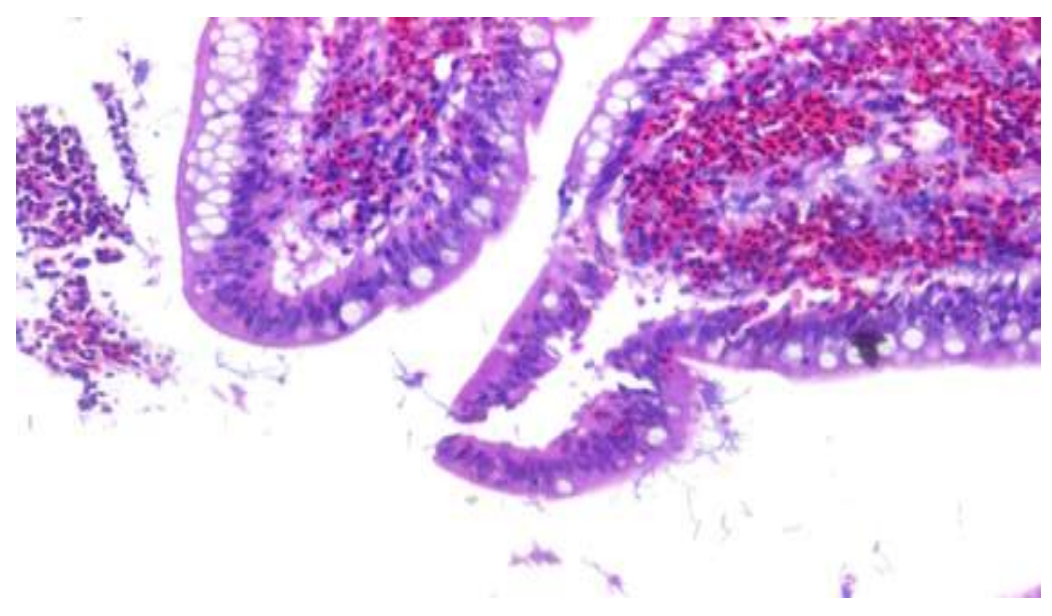

Fig.14 Section of jejunum from Clostridia challenged (T2) bird to show adherence of organisms to the epithelial cell surface of tunica mucosa on day 26th of the experiment. H\&E X 1000

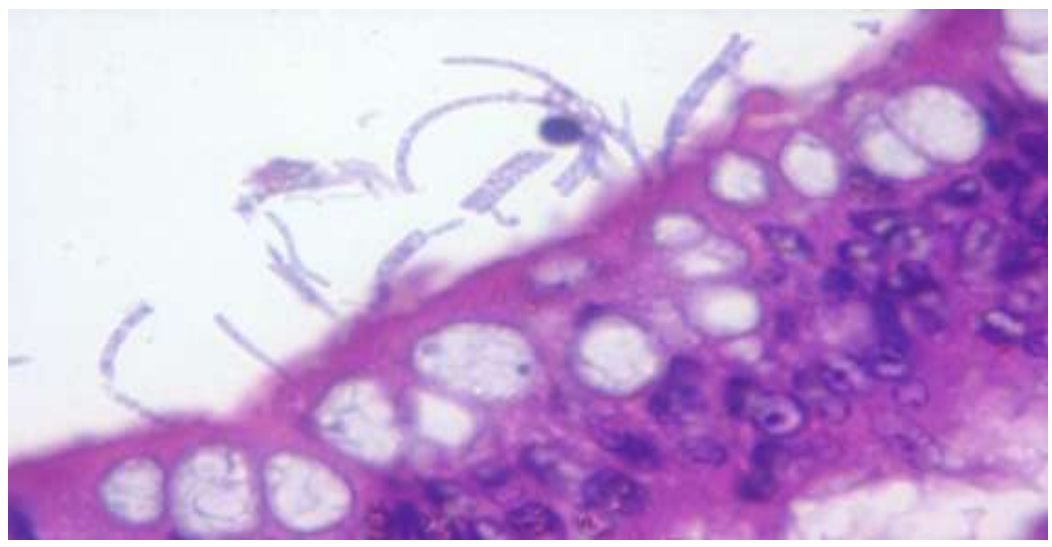


Fig.15 Section of jejinum from Clostridia challenged (T2) bird to show Clostridial organisms colonized on the surface epithelium. H\&E X

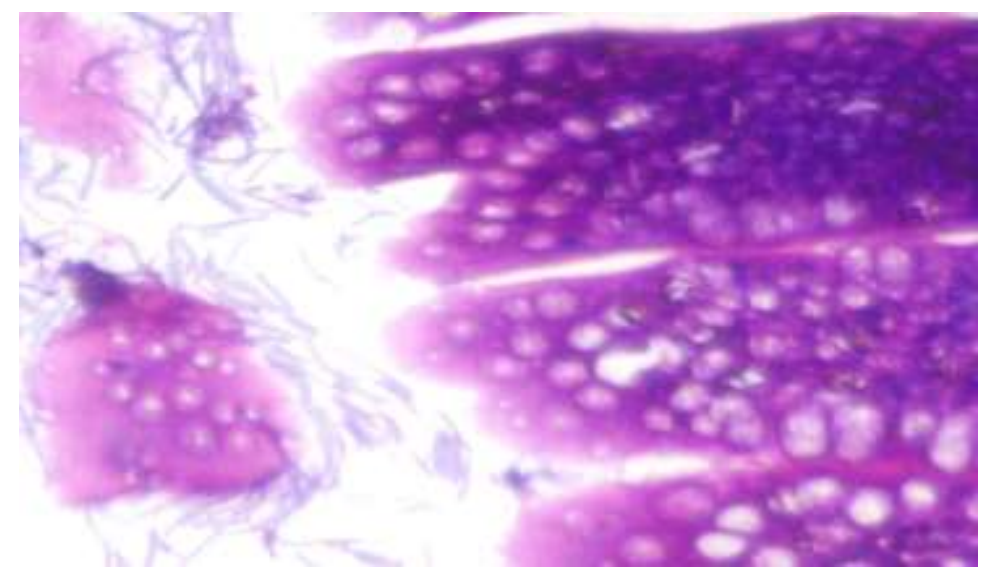

Fig.16 Photomicrograph of Caecum from Normal control bird (T1) to show normal appearance on 24th day of the experiment. H\&E X 100

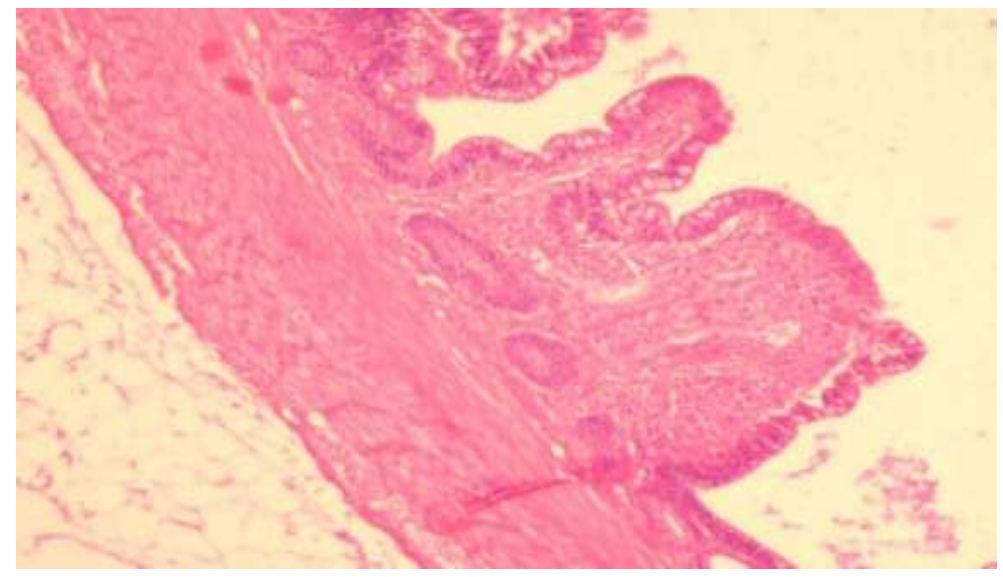

Fig.17 Photomicrograph of Caecum from Clostridia challenged (T2) bird in higher magnification to show attachment of cluster of gram positive Clostridial organisms to cell surface on 24th day of the experiment (H\&E X 1000)

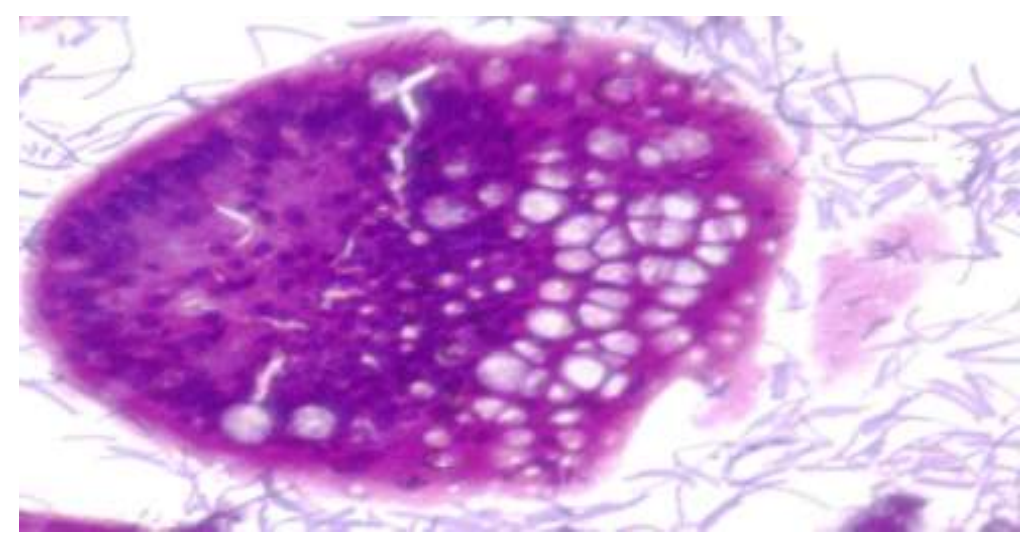


Fig.18 Section of ileo-ceacal junction from Clostridia challenged (T2) bird to show denudation and desquamation of superficial epithelial layer of the tunica submucosa on 26th day of the study. H\&E X 40

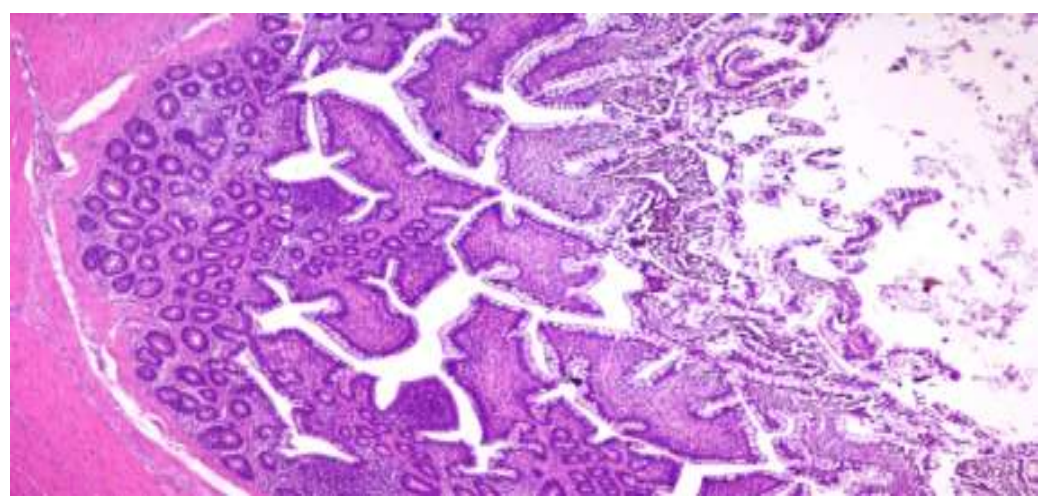

Fig.19 Photomicrograph of Caecum from Clostridia challenged (T2) bird in higher magnification to show haemorrhages at the tip of mucosa, segmental loss of surface epithelium due to necrosis on 24 th day of the study. H\&E X 40

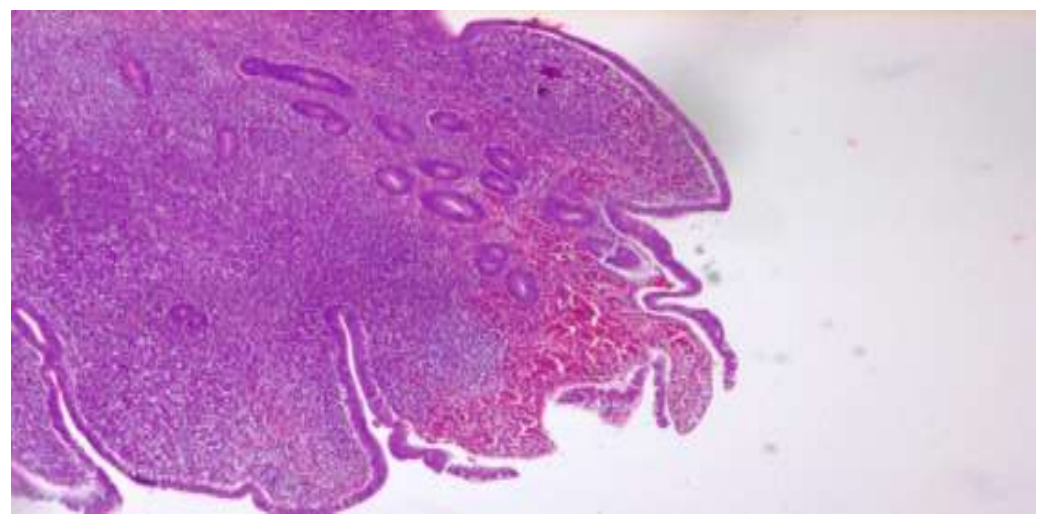

Fig.20 Liver section from Clostridia challenged (T2) bird to show focal area of necrosis around the central vein and infiltration of mononuclear cells with vacuolar changes in hepatocytes on 24th day of the experiment. H\&E X 200

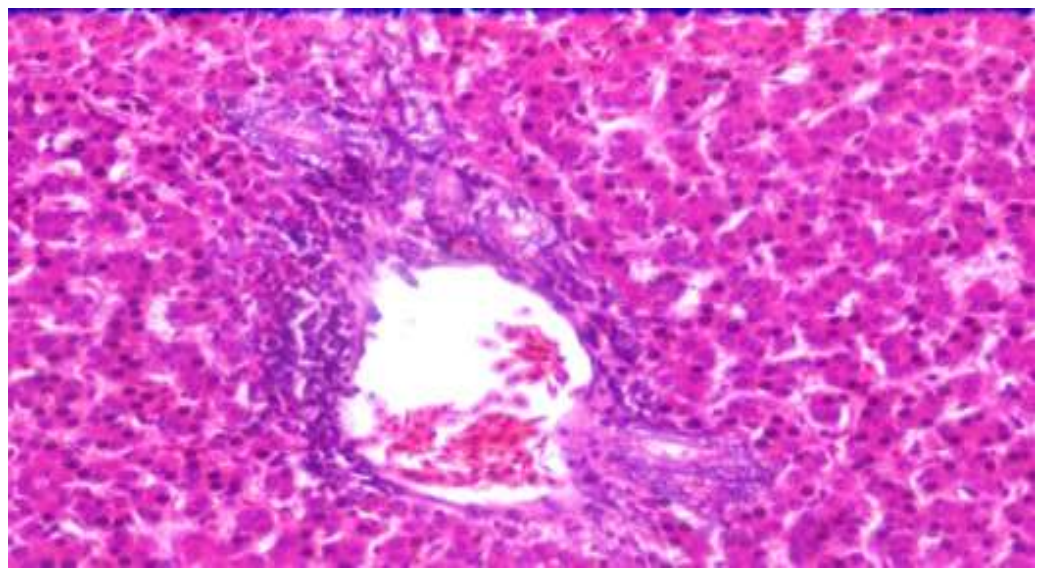


Fig.21 Liver section from Clostridia challenged (T2) bird to show vacuolar changes in the hepatocytes, congested vessels, necrosis and mononuclear cell infiltration. (H\&E X 200)

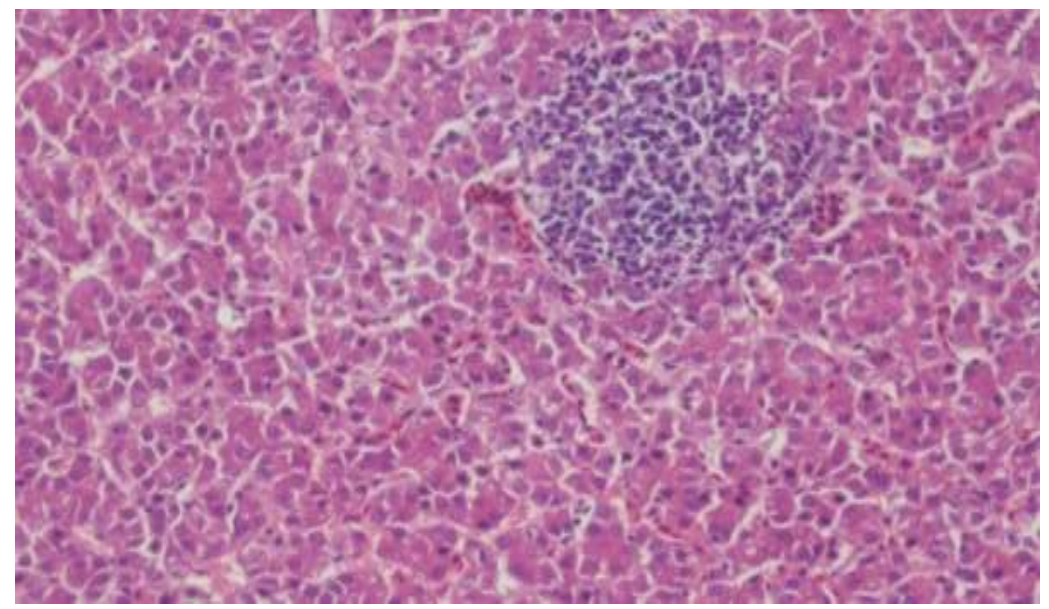

Fig.22 Photomicrograph of liver from Normal control (T1) bird to show normal morphology on day 26th of the study. (H\&E X 100)

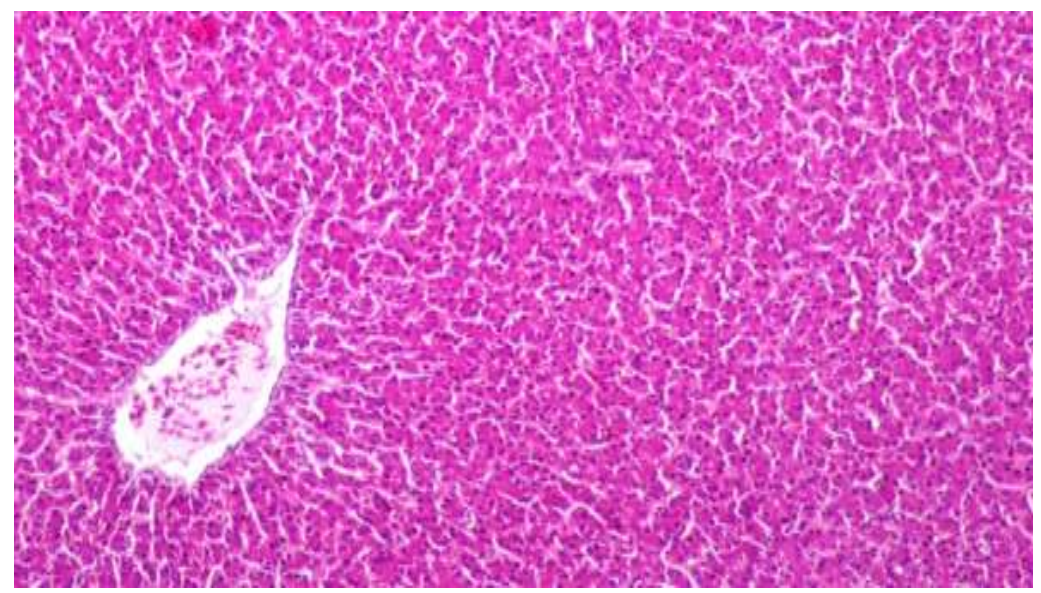

\section{Liver}

Clostridia challenged (T2) birds revealed mild congestion, vacuolar degeneration of the hepatocytes, mild fatty change in occasional areas, small multifocal areas of fibrinoid necrosis and mild periportal mononuclear cell infiltration with cholangiolar hyperplasia were attributed to effect caused by Clostridium perfringens organisms. Similar observations were noticed by Lovland and Kaldhusdal, (2001).Birds in the normal control group did not show any lesions on histopathological examination (Fig. 20- 22).
It is concluded that, necrotic Enteritis could effectively be induced by oral administration of Clostridium perfringens at the dose rate of $4 \times 10^{8}$ colony forming units per bird thrice a day, for four consecutive days induced in broiler chicken. There was significant decrease in the feed consumption and FCR of birds induced with Necrotic Enteritis The birds with Necrotic Enteritis showed a significant increase in the mean serum AST and ALT values and significant reduction in the total protein levels. 


\section{Acknowledgment}

I sincerely thank Dean, Veterinary College Bengaluru and Director IAH\&VB for their unconditional generous help provided in terms of research facilities, technical guidance and motivation in carrying out the present work. I cannot forget to extend my sincere thanks to senior and junior friends for their moral support in carrying out present work.

\section{References}

Baba, E., Fuller, A.L., Gilbert, J.M., Thayer, S.G. and Mc Dougald, L.R., 1992. Effects of Eimeria brunetti infection and dietary zinc on experimental induction of Necrotic Enteritis in broiler chickens. Avian. Dis., 36(1): 59-62

Broussard, C.T., Hofacre, C.L., Page, R.K. and Fletcher, O.J., $1986 . \quad$ Necrotic Enteritis in cage-reared commercial layer pullets. Avian. Dis., 30(3): 617619

Gholamiandehkordi, A.R., Timbermont, L., Lanckriet, A., Broeck, D.V.M., Pedersen, K., Dewulf, J., Pasmans, F., Haesebrouck, F., Ducatelle, R. and Van Immerseel, F., 2007. Quantification of gut lesions in a subclinical Necrotic Enteritis model. Avian. Pathol., 36(5): 375-382.

Kaldhusdal, M. and Hofshagen, M., 1992. Barley inclusion and avoparcin supplementation in broiler diets. 2 . Clinical, pathological, and bacteriological findings in a mild form of Necrotic Enteritis. Poult Sci., 71(7): 1145-1153.

Kaldhusdal, M., Hofshagen, M., Lovland, A., Langstrand, H. and Redhead, K., 1999. Necrotic Enteritis challenge models with broiler chickens raised on litter: evaluation of preconditions, Clostridium perfringens strains and outcome variables. FEMS. Immunol. Med. Mic., 24: 337-343.

Keyburn, A.L., Xu-Xia Yan, Bannam, T.L., Van Immerseel, F., Rood, J.I. and Moore R.J., 2010. Association between avian Necrotic Enteritis and Clostridium perfringens strains expressing NetB toxin. Vet. Res., 41:21.

Lanckriet, A., Timbermont, L., De Gussem, M., Marien, M., Vancraeynest, D., Haesebrouck, F., Ducatelle, R. and Van Immerseel, F., 2010. The effect of commonly used anticoccidials and antibiotics in a subclinical Necrotic Enteritis model. Avian. Pathol., 39(1): 63-68.

Long, J.R., Pettit, J.R. and Barnum, D.A., 1974. Necrotic Enteritis in broiler chickens. II. Pathology and proposed pathogenesis. Can. J. Comp. Med., 38:467-474

Lovland, A. and Kaldhusdal, M., 1998. Liver lesions seen at slaughter as an indicator of Necrotic Enteritis in broiler. FEMS. Immunol. Med. Mic., 24: 345-351

Lovland, A. and Kaldhusdal, M., 2001. Severely impaired production performance in broiler flocks with high incidence of Clostridium perfringens associated hepatitis. Avian Pathol., 30: 73-81.

Luna, L.G., 1968. Routine Staining Procedures In: Manual of Histologic Staining Methods of the Armed Forces Institute of Pathology. $E d n . \quad 3^{\text {rd }}$ McGraw-Hill, New York., pp 32-46

Olkowski, A.A., Wojnarowicz, C., ChirinoTrejo, M. and Drew, M.D., 2006. Responses of broiler chickens orally challenged with Clostridium perfringens isolated from field cases of Necrotic Enteritis. Res. Vet. Sci., 81: 99-108.

Pedersen K., Bjerrum, L., Heuer, O.E., Lo Fo 
Wong, D.M.A. and Nauerby, B., 2008. Reproducible infection model for Clostridium perfringens in broiler chickens. Avian Dis., 52: 34-39.

Shane, J.E., Gyimah, K.S., Harrington. and Snider, T.G., 1985. Etiology and pathogenesis of necrotic enteritis. Vet. Res. Commun., 9: 269-287.

Smyth, J.A. and Martin, T.G., 2010. Disease producing capability of NetB positive isolates of Clostridium perfringens recovered from normal chickens and a cow, and NetB positive and negative isolates from chickens with Necrotic Enteritis. Vet. Microbiol., 146: 76-84.

Songer, J.G. and Meer, R.R., 1997. Multiplex polymerase chain reaction assay for genotyping Clostridium perfringens. Am. J. Vet. Res., 58(7): 702-705.

\section{How to cite this article:}

Suryakanth, K.C., M.L. Sathyanarayan, K.C. Mallinath, H.D. Narayanaswamy, Shravan kumar $^{1}$, G. Sugunarao, Upendra and Shridhar, N.B. 2019. Study on Pathomorphological and Biochemical changes in Experimentally Induced Necrotic Enteritis in Broiler Chicken. Int.J.Curr.Microbiol.App.Sci. 8(01): 2795-2810. doi: https://doi.org/10.20546/ijcmas.2019.801.294 